\title{
APPLICATION OF THEORY OF PLANNED BEHAVIOR IN SHRIMP CONSUMER BEHAVIOR ANALYSIS
}

\author{
Anindila Fitria Ghifarini \\ Bogor Agricultural University, Indonesia \\ E-mail: anindila.fitria@gmail.com \\ Ujang Sumarwan \\ Bogor Agricultural University, Indonesia \\ E-mail: sumarwan@apps.ipb.ac.id \\ Mukhamad Najib \\ Bogor Agricultural University, Indonesia \\ E-mail: najib@ipb.ac.id \\ Submission: $23 / 07 / 2017$ \\ Revision: 06/03/2018 \\ Accept: 31/03/2018
}

\section{ABSTRACT}

Although the export orientation of shrimp commodities in developing fisheries sector is very influential and has a great contribution in the country's economic development, but there are still many obstacles encountered in shrimp exports. Besides, domestic market can be an alternative choice for shrimp market. Understanding consumer behavior towards shrimp is very important for producers and government in order to know how consumers' intention in shrimp consumption. Therefore, in this study conducted a consumer behavior analysis of shrimp to determine intention in shrimp consumption in Indonesia by using The Theory of Planned Behavior (TPB). This research aimed to analyze the characteristics of shrimp consumers, to analyze the contribution of attitudes toward behavior, subjective norms, and behavioral control and formulate market education strategy which can increase the consumption of shrimp. Descriptively, the results of the distribution of questionnaires showed that majority of shrimp consumers were less than 30 years old, with private employment type and housewives. 
INDEPENDENT JOURNAL OF MANAGEMENT \& PRODUCTION (IJM\&P)

http://www.ijmp.jor.br

v. 9, n. 3, July - September 2018

ISSN: 2236-269X

DOI: 10.14807/ijmp.v9i3.705

The result of model Theory of Planned Behavior toward shrimp consumer behavior shows that there is a significant affects directly to intention which is from Subjective Norm. The influence of the environment are greatly affects consumers in taking decisions before making a purchase of shrimp products. The government in its program or policy has initiated an approach to the domestic consumers of seafood products in order to create high attention of people to consume fishery products.

Keywords: Intention, Shrimp, Theory of Planned Behavior

\section{INTRODUCTION}

Fishery products is one of the potential products in Indonesia. As an archipelagic state, the potential of fishery resources has a large contribution to the country's Gross Domestic Product (GDP). GDP data in 2013 shows that the fishery sector has the second largest contribution after the crops sector, with percentages of $22.6 \%$ and $47.43 \%$ respectively.

The fishery industry has also contributed as much as $2.87 \%$ of the total value of Indonesia's non-oil and gas exports in 2013. The value of fishery commodity exports in 2013 reached US \$4,181,457,000, which is dominated by shrimp commodities (KKP, 2014).

Although the export orientation of shrimp commodities in developing fisheries sector is very influential and has a great contribution in the country's economic development, but there are still many obstacles encountered in shrimp exports. There are still many challenges of global competition with other countries. Besides, domestic market can be an alternative choice for fisheries companies.

The Successful growth of capture fisheries and cultivation can contribute significantly to the future for food security and nutrition also the needs of Indonesia's economic development. During 2015, the results of data acquisition system of aquaculture in Indonesia obtained that Indonesia is able to produce 623,000 tons of shrimp per year.

In addition to the availability of abundant products, shrimp market opportunities can be seen from various aspects. First, the increasing population of Indonesian society. The population of Indonesia is estimated to have reached 252 million people by now. Secondly, the increase in people's purchasing power. 
This is indicated by an increase in monthly per capita expenditure on fishery consumption in 2011 amounting to Rp 25,369.00 (BPS, 2011) and in 2014 amounting to $\mathrm{Rp} 33,231.00$ (BPS, 2014), while expenditure for shrimp consumption per capita per month in year 2011 amounted to Rp 1,996.00 (BPS, 2011) and in 2014 increased to Rp 2,456.00 (BPS, 2014).

Third, the government program which proclaimed by the Ministry of Maritime Affairs and Fisheries is the Movement to Socialize Fishery Products (GEMARIKAN) become a very promising opportunity. This program has been conducted by the government since 2004. The existence of the "Gemarikan" campaign has shown that there is a tendency to shift people's preference to consume shrimp as a potential fishery commodity.

Based on the above description, it shows that shrimp is a potential commodity. Understanding consumer behavior towards shrimp is very important for producers and government in order to help "Gemarikan" program. Therefore, in this study conducted a consumer behavior analysis of shrimp to determine interest in shrimp consumption in Indonesia by using The Theory of Planned Behavior (TPB).

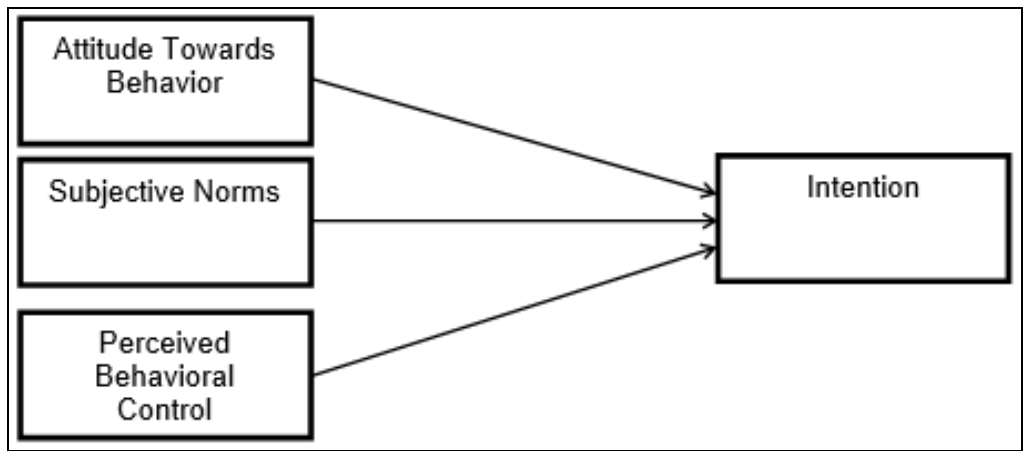

Figure 1: Theory of Planned Behavior (AJZEN, 1991)

Based on TPB (AJZEN, 1991), the formation of consumer attitudes will form a person intention to perform or not to perform an action, in this case the purchase of shrimp. Thus, shrimp purchasing behavior indirectly can be predicted through behavior intention or intention to buy shrimp. Theory of Planned Behavior (TPB) has also been used in explaining the behavior of fish consumption especially in some western countries such as Norway (OLSEN, 2001; HONKANEN et al., 2005), Belgium (VERBEKE AND VACKIER, 2005), Romania (FOTEA et al., 2012 ), Brazil (DALTOE et al., 2013), and Croatia (TOMl et al., 2016). It is also done in North America (LAUBER et al., 2011) and Australia (BIRCH AND LAWLEY, 2010). In Asia, 
INDEPENDENT JOURNAL OF MANAGEMENT \& PRODUCTION (IJM\&P)

http://www.ijmp.jor.br

v. 9, n. 3, July - September 2018

ISSN: 2236-269X

DOI: 10.14807/ijmp.v9i3.705

it is known to have conducted research on fish consumption behavior with TPB approach that is in Vietnam (TUU et al., 2008; TUU et al., 2010; THOM, 2007; THONG AND OLSEN, 2012). However, it has never been done in Indonesia and has never been applied to shrimp commodities.

This research aimed to analyze the characteristics of shrimp consumers, to analyze the contribution of attitudes toward behavior, subjective norms, and behavioral control (Figure 1) to the intention to consume shrimp and formulate market education strategy which can increase the consumption of shrimp.

\section{RESEARCH METHOD}

This research was conducted from January to February 2016 in Bogor, West Java, Indonesia. The Selection of research location because in Bogor is one region that has run "Gemarikan" campaign. The data used in this research are primary data and secondary data. Primary data collection is obtained directly by distributing questionnaires that are structured offline and online using non-probability sampling method with purposive sampling. The following table shows variables and indicators in this research.

Table 1: Research variables and indicators

\begin{tabular}{|c|c|c|c|}
\hline Latent Variables & Aspect & Indicator Variables & Symbol \\
\hline \multirow{2}{*}{$\begin{array}{ll}\text { Attitude } & \text { Towards } \\
\text { Behavior } & \end{array}$} & Behavior beliefs & $\begin{array}{l}\text { Health } \\
\text { Distinctive flavor } \\
\text { Good taste } \\
\text { Nutritional content }\end{array}$ & $\begin{array}{l}X_{1} \\
X_{2} \\
X_{3} \\
X_{4}\end{array}$ \\
\hline & $\begin{array}{l}\text { Outcome } \\
\text { evaluation }\end{array}$ & $\begin{array}{l}\text { The importance of health } \\
\text { The importance of distinctive flavor } \\
\text { The importance of good taste } \\
\text { The importance of nutritional } \\
\text { content }\end{array}$ & $\begin{array}{l}X_{5} \\
X_{6} \\
X_{7} \\
X_{8}\end{array}$ \\
\hline \multirow{2}{*}{ Subjective Norms } & $\begin{array}{l}\text { Normative } \\
\text { Beliefs }\end{array}$ & $\begin{array}{l}\text { Family } \\
\text { Friends/relatives } \\
\text { Doctor/nutritionist } \\
\text { Goverment }\end{array}$ & $\begin{array}{l}X_{9} \\
X_{10} \\
X_{11} \\
X_{12}\end{array}$ \\
\hline & $\begin{array}{l}\text { Motivation to } \\
\text { Comply }\end{array}$ & $\begin{array}{l}\text { Family } \\
\text { Friends/relatives } \\
\text { Doctor/nutritionist } \\
\text { Goverment }\end{array}$ & $\begin{array}{l}X_{13} \\
X_{14} \\
X_{15} \\
X_{16}\end{array}$ \\
\hline \multirow{2}{*}{$\begin{array}{l}\text { Perceived } \\
\text { Behavioural } \\
\text { Control }\end{array}$} & Control Beliefs & $\begin{array}{l}\text { Financial issue } \\
\text { Availability of shrimp } \\
\text { Health (allergic, etc) }\end{array}$ & $\begin{array}{l}\mathrm{X}_{17} \\
\mathrm{X}_{18} \\
\mathrm{X}_{19}\end{array}$ \\
\hline & $\begin{array}{l}\text { Power of } \\
\text { Control Factors }\end{array}$ & $\begin{array}{l}\text { Sufficiency of money } \\
\text { Abundant availability } \\
\text { Health support }\end{array}$ & $\begin{array}{l}X_{20} \\
X_{21} \\
X_{22}\end{array}$ \\
\hline Intention & & $\begin{array}{l}\text { Intention to consume shrimp once a week } \\
\text { Intention to consume shrimp in restaurant }\end{array}$ & $\begin{array}{l}Y_{1} \\
Y_{2}\end{array}$ \\
\hline
\end{tabular}


The Sample is collected by using the rule of thumb from Structural Equation Modeling (SEM). The number of indicator variables in this study are 24 indicator variables, and the number of respondents are 120 respondents.

The independent variables consist of attitudes toward behavior, subjective norms, and perceived behavioral control. Meanwhile, the intention to buy shrimp in Bogor is the dependent variable (Table 1). The four variables are measured through the statements contained in the questionnaire.

The scaling technique used is semantic different scale in five variations of the answer. The statistic analysis used is Partial Least Square (PLS - SEM) with SmartPLS 3.0 software. The results will find out what attributes that affect public interest on shrimp consumption.

The SEM Hybrid Model is an overall model that includes structural models and measurement models. The Model of Hybrid (Full SEM Model) from this research can be seen in Figure 2.

\section{RESULT AND DISCUSSION}

\subsection{Profile Respondent}

Various characteristics of respondents such as demographic, social, economic and consumer characteristics of respondents have been examined in this study. Studies show that age and gender influence a person's purchasing decision toward a product.

Based on the results of data processing on the characteristics of respondents who consume shrimp, there are $58.3 \%$ of respondents which are $<30$ years old and women seen more in consuming shrimp, which is as much as $60 \%$ when compared with men.

The results showed that the intention of female respondents greater than men. Therefore, producers can focus on digging what women love from a food product. 
INDEPENDENT JOURNAL OF MANAGEMENT \& PRODUCTION (IJM\&P)

http://www.ijmp.jor.br

v. 9, n. 3, July - September 2018

ISSN: 2236-269X

DOI: 10.14807/ijmp.v9i3.705

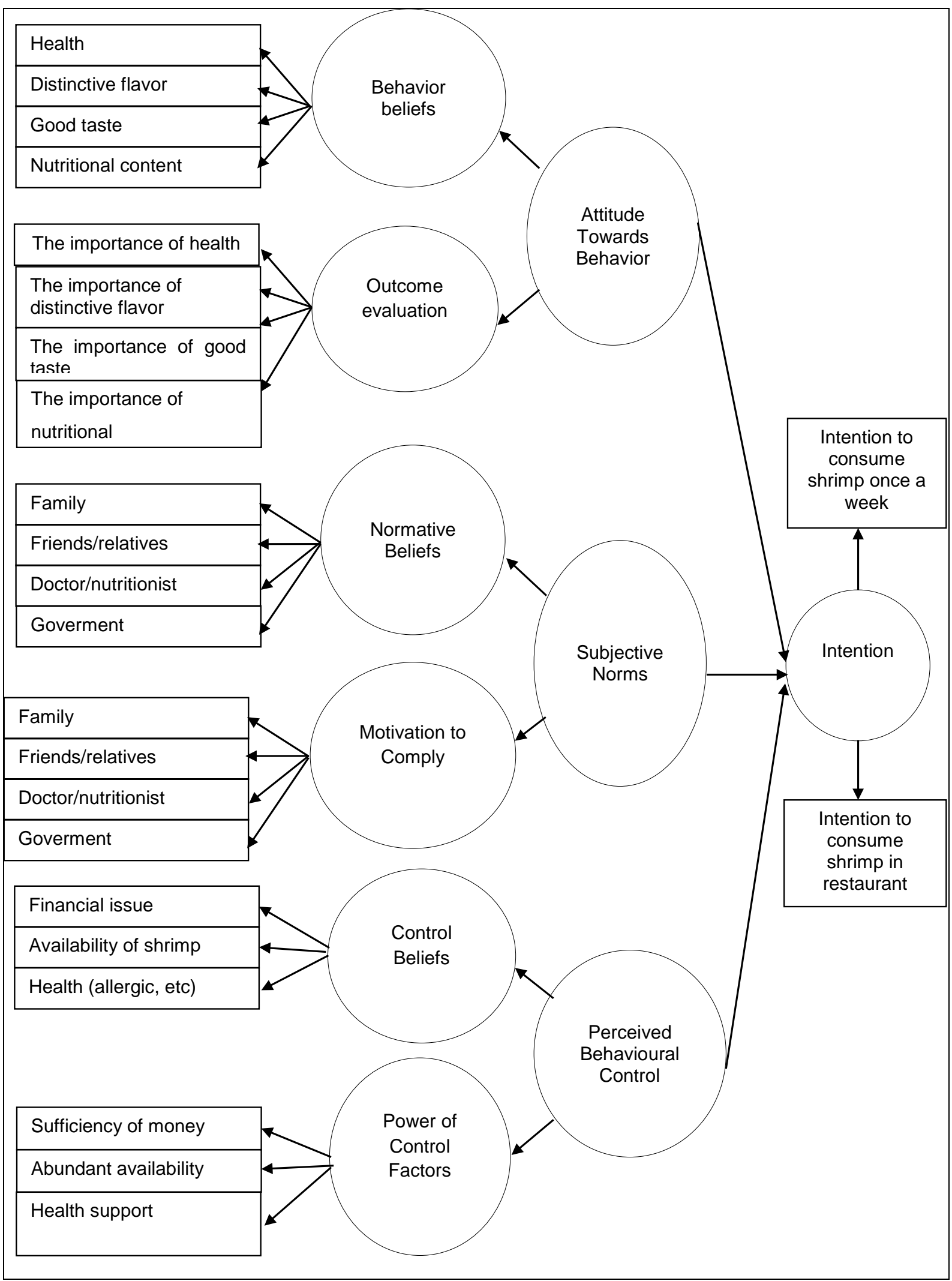

Figure 2: SEM Hybrid Model in the intention of shrimp consumption 
INDEPENDENT JOURNAL OF MANAGEMENT \& PRODUCTION (IJM\&P)

http://www.ijmp.jor.br

v. 9, n. 3, July - September 2018

ISSN: 2236-269X

DOI: 10.14807/ijmp.v9i3.705

The recommended age is under 30 years. At this age, they currently very intensive to use social media or sometimes called a millenials generation. The results of research that has been done by Barton et al (2012) about millenials generation which consists of aged 16-34 years. Millennials love to try something new.

This generation forms the preference of a trademark or store. Generation millenials make purchases of food based on the influence of family, friends, or people they just know.

Table 2: Social and economic characteristics of respondents

\begin{tabular}{|c|c|c|c|}
\hline Respondent Characteristic & Category & $\begin{array}{l}\text { Respondent } \\
\text { Frequency }\end{array}$ & $\begin{array}{l}\text { Relative } \\
\text { Frequency } \\
(\%)\end{array}$ \\
\hline \multirow{6}{*}{$\begin{array}{l}\text { Total expenditure for food } \\
\text { consumption per month } \\
\text { (Rp) }\end{array}$} & $<1.000 .000$ & 24 & 20.00 \\
\hline & $1.000 .000-2.000 .000$ & 58 & 48.33 \\
\hline & $2.000 .001-3.000 .000$ & 18 & 15.00 \\
\hline & $3.000 .000-4.000 .000$ & 6 & 5.00 \\
\hline & $4.000 .001-5.000 .000$ & 7 & 5.83 \\
\hline & $>\operatorname{Rp} 5.000 .000$ & 7 & 5.83 \\
\hline \multirow{6}{*}{$\begin{array}{l}\text { Total Income per month } \\
\text { (Rp) }\end{array}$} & $<\operatorname{Rp} 1.000 .000$ & 5 & 4.16 \\
\hline & $1.000 .000-3.000 .000$ & 35 & 29.16 \\
\hline & $3.000 .001-5.000 .000$ & 42 & 35.00 \\
\hline & $5.000 .001-10.000 .000$ & 22 & 18.33 \\
\hline & $10.000 .000-20.000 .000$ & 12 & 10.00 \\
\hline & $>\operatorname{Rp} 20.000 .000$ & 4 & 3.33 \\
\hline
\end{tabular}

Table 2 discuss about the social and economic characteristics of respondents. From the table can be seen that 42 respondent or represent 35\% of all respondents who have monthly income between Rp 3.000.000 - Rp 5.000.000. If added, as many as 80 respondents from 120 total, have income above $\mathrm{Rp} 3.000 .000$ to reach $\mathrm{Rp}$ 20.0000.000 per month. This proves that the level of education and income a person can give a positive influence on the purchase of shrimp. The high of shrimp's prices and the high nutrition in shrimp are tend to make respondents choose to buy shrimp as their meal menu.

Sumarwan (2011) states that the level of education is one of the several consumer's factors in making decisions to consume or buy a product or brand. A person's consumption pattern is closely related to the level of income which received for the allocation of the fulfillment of his or her life's needs. Revenue is often combined with other demographic variables such as education and employment.

Table 3 presented the characteristics of respondent's consumption of shrimp in Bogor. It can be seen from the frequency of consumption, $66.67 \%$ of respondents 
INDEPENDENT JOURNAL OF MANAGEMENT \& PRODUCTION (IJM\&P)

http://www.ijmp.jor.br

v. 9, n. 3, July - September 2018

ISSN: 2236-269X

DOI: 10.14807/ijmp.v9i3.705

are uncertain in consuming shrimp. This indicates that respondents do not plan to consume shrimp, only if they wish. In addition, as many as 30\% of respondents last consumed shrimp is about 1 month ago.

Table 3: Characteristics of respondent's consumption

\begin{tabular}{|c|c|c|c|}
\hline $\begin{array}{c}\text { Respondent } \\
\text { Characteristic }\end{array}$ & Category & $\begin{array}{c}\text { Respondent } \\
\text { Frequency }\end{array}$ & $\begin{array}{c}\text { Relative } \\
\text { Frequency } \\
\text { (\%) }\end{array}$ \\
\hline $\begin{array}{c}\text { Frequency of } \\
\text { consumption }\end{array}$ & Once a week & 22 & 18.33 \\
\hline & Twice a week & 8 & 6.66 \\
\hline & 3 times a week & 5 & 4.16 \\
\hline & uncertain & 80 & 66.66 \\
\hline $\begin{array}{c}\text { Last consumption of } \\
\text { shrimp }\end{array}$ & Others & 5 & 4.16 \\
\hline & One month ago & 36 & 30.00 \\
\hline & 2 weeks ago & 13 & 10.80 \\
\hline & 1 week ago & 30 & 25.00 \\
\hline & 1 day ago & 26 & 21.70 \\
\hline & $>1$ month ago & 7 & 5.80 \\
\hline & 2 - 6 days ago & 5 & 4.20 \\
\hline & Others & 3 & 2.50 \\
\hline
\end{tabular}

It can be concluded that the frequency of respondents in consuming shrimp is still low. It can also be proved from the last time respondents consume shrimp is one week up to one month ago. The price of shrimp can be a factor in the low level of shrimp consumption. Shrimps have prices that tend to be higher than any other seafood products or other types of freshwater fish. The price of $1 \mathrm{Kgs}$ vaname shrimp reach Rp. 90.000, while the price of $1 \mathrm{~kg}$ of mackerel only Rp. 35,000/kgs and Rp. 45.000/kgs for carp.

The availability of shrimp products in Bogor City is also an important factor. The city of Bogor is geographically far from the sea. Often consumers find it difficult to get seafood products and tend to consume freshwater fish.

\subsection{Respondent Behaviour}

The results showed that 76 respondents consumed the shrimp because it tasted good and 96 respondents liked to consume shrimp in the form of fresh shrimp (fresh shrimp), then processed itself according to taste. A total of 73 respondents bought $<1 \mathrm{~kg}$ of shrimp in a single purchase. This can be due to the respondents making purchases as needed.

As many as 78 respondents chose fried as a favorite processed form in consuming shrimp. The ease of processing technique remains the respondent's 
INDEPENDENT JOURNAL OF MANAGEMENT \& PRODUCTION (IJM\&P)

http://www.ijmp.jor.br

v. 9, n. 3, July - September 2018

ISSN: 2236-269X

DOI: 10.14807/ijmp.v9i3.705

choice. In accordance with the character of the Indonesian people, respondents like the food in the way with the fried.

A total of 40 respondents took a decision in the purchase of shrimp that depends on the current situation. While 37 respondents planned to buy shrimp from home. These results indicate that current decisions depend on current needs and prices, promotions or discounts increase sales.

\subsection{Theory of Planned Behaviour}

The following table is respondent frequency of attitudes toward behavior, subjective norms, behavior control, and shrimp consumption intention.

Table 4: Frequency of attitudes toward behavior, subjective norms, behavior control, and shrimp consumption intention

\begin{tabular}{|c|c|c|c|}
\hline \multirow{2}{*}{ Indicator Variable } & \multicolumn{3}{|c|}{ Respondent Frequency } \\
\hline & Disagree & Normal & Agree \\
\hline \multicolumn{4}{|c|}{ Behavior Beliefs } \\
\hline Health & 9 & 34 & 77 \\
\hline Distinctive flavor & 5 & 24 & 91 \\
\hline Good taste & 9 & 39 & 72 \\
\hline Nutritional content & 7 & 34 & 79 \\
\hline \multicolumn{4}{|c|}{ Outcome Evaluation } \\
\hline The importance of health & 18 & 49 & 53 \\
\hline The importance of distinctive flavor & 11 & 39 & 70 \\
\hline The importance of good taste & 7 & 27 & 86 \\
\hline The importance of nutritional & 10 & 45 & 65 \\
\hline \multicolumn{4}{|c|}{ Normative Beliefs } \\
\hline Family & 29 & 53 & 17 \\
\hline Friends/relatives & 29 & 50 & 21 \\
\hline Doctor/nutritionist & 37 & 49 & 14 \\
\hline Goverment & 23 & 36 & 41 \\
\hline \multicolumn{4}{|c|}{ Motivation to Comply } \\
\hline Family & 25 & 50 & 25 \\
\hline Friends/relatives & 21 & 51 & 28 \\
\hline Doctor/nutritionist & 21 & 51 & 28 \\
\hline Goverment & 17 & 37 & 47 \\
\hline \multicolumn{4}{|c|}{ Control Beliefs } \\
\hline Financial issue & 12 & 36 & 72 \\
\hline Availability of shrimp & 6 & 31 & 83 \\
\hline Health (allergic, etc) & 4 & 20 & 96 \\
\hline \multicolumn{4}{|c|}{ Power of Control } \\
\hline Sufficiency of money & 8 & 36 & 76 \\
\hline Abundant availability & 6 & 31 & 83 \\
\hline Health support & 7 & 29 & 84 \\
\hline Intention to consume shrimp once a week & 24 & 47 & 49 \\
\hline Intention to consume shrimp in restaurant & 28 & 44 & 48 \\
\hline
\end{tabular}

Table 4 explains that as many as $70 \%$ of respondents belief that shrimp has a distinctive and a good taste. In addition, Table 4 also shows that family, friends or 
INDEPENDENT JOURNAL OF MANAGEMENT \& PRODUCTION (IJM\&P)

http://www.ijmp.jor.br

v. 9, n. 3, July - September 2018

ISSN: 2236-269X

DOI: 10.14807/ijmp.v9i3.705

relatives, as well as nutritionists do not intervene much to the respondents to consume shrimp. This can be seen from the average percentage of the three statements. Interestingly, the influence of the government from one of the programs that are being encouraged is "Gemarikan" which turned out to get a positive intention.

Table 5 shows the results of chi-square test between the characteristics of respondents and intentions of shrimp consumption.

Table 5: Chi-square test results between the characteristics of respondents and intentions

\begin{tabular}{|c|c|c|c|c|c|}
\hline \multirow{2}{*}{\multicolumn{2}{|c|}{ Respondent Characteristic }} & \multicolumn{3}{|c|}{ Consumption Intensity (\%) } & \multirow{3}{*}{$\begin{array}{c}\text { p-value } \\
\text { Chi-(square) }\end{array}$} \\
\hline & & \multirow{2}{*}{$\begin{array}{r}\text { Low } \\
13.33 \\
\end{array}$} & \multirow{2}{*}{$\begin{array}{c}\begin{array}{c}\text { Modera } \\
\text { te }\end{array} \\
24.58\end{array}$} & \multirow{2}{*}{$\begin{array}{l}\text { High } \\
20.42\end{array}$} & \\
\hline Age & $<30$ yo & & & & \\
\hline & $31-40$ yo & 3.33 & 7.08 & 12.92 & \multirow[t]{2}{*}{$0.532^{\mathrm{tn}}$} \\
\hline & $>40$ yo & 5.00 & 12.92 & 17.50 & \\
\hline \multirow[t]{2}{*}{ Gender } & Male & 11.25 & 17.92 & 10.83 & \multirow{5}{*}{$0.218^{\mathrm{tn}}$} \\
\hline & Female & 10.42 & 20.00 & 29.58 & \\
\hline \multirow[t]{3}{*}{ Marital Status } & Single & 8.33 & 13.75 & 20.42 & \\
\hline & Widow/widower & 0.00 & 0.00 & 1.67 & \\
\hline & Married & 13.33 & 24.17 & 18.33 & \\
\hline \multirow[t]{3}{*}{ Last Education } & College (S1/S2) & 12.92 & 25.42 & 34.17 & \multirow{3}{*}{$0.862^{\text {tn }}$} \\
\hline & Diploma & 4.58 & 5.00 & 3.75 & \\
\hline & High School & 4.17 & 7.50 & 2.50 & \\
\hline \multirow[t]{6}{*}{ Type of work } & Housewives & 5.00 & 8.75 & 10.42 & \multirow{6}{*}{$0.043^{*}$} \\
\hline & Student & 1.67 & 2.08 & 5.42 & \\
\hline & Civil Servant & 1.67 & 2.92 & 5.42 & \\
\hline & Private employees & 9.17 & 15.83 & 16.67 & \\
\hline & Unemployed & 0.00 & 0.00 & 0.00 & \\
\hline & Enterpreneur & 4.17 & 8.33 & 2.50 & \\
\hline
\end{tabular}

Description: *) significant correlation at $5 \%$ real level, tn) correlation is not significant.

The results can be seen in Table 5, shows that the type of work is the only characteristics of respondents who have a significant correlation with intention to consume shrimp. The types of work are grouped into six types. The highest percentage of consumption intensity is in the profession of respondents as private employees, the second is as a housewives. Each intensity percentage is $16.67 \%$ and $10.42 \%$ respectively.

\subsection{Evaluation of Measurement Model (Outer Model)}

According to Gozali (2012), there are three criteria in using analysis technique with SmartPLS that is to assess the outer model such as convergent validity, discriminant validity, and composite reliability. Validity test can be seen from loading factor value for each indicator. The rule of thumb value of loading factor is $0.6-0.7$ 
INDEPENDENT JOURNAL OF MANAGEMENT \& PRODUCTION (IJM\&P)

http://www.ijmp.jor.br

v. 9, n. 3, July - September 2018

ISSN: 2236-269X

DOI: 10.14807/ijmp.v9i3.705

for exploratory research. However, for the early stage of developing of measurement scale, the loading factor value of $0.5-0.6$ is still considered sufficient (CHIN, 1998). In this phase of research will be used limit factor of 0.6.

Table 6: Outer Loadings Value

\begin{tabular}{|c|c|c|c|}
\hline Latent Variables & Aspect & Indicator Variables & Symbol \\
\hline \multirow[b]{2}{*}{$\begin{array}{l}\text { Attitude Towards } \\
\text { Behavior }\end{array}$} & $\begin{array}{l}\text { Behavior } \\
\text { beliefs }\end{array}$ & $\begin{array}{l}\text { Health } \\
\text { Distinctive flavor } \\
\text { Good taste } \\
\text { Nutritional content }\end{array}$ & $\begin{array}{l}0.695 \\
0.824 \\
0.803 \\
0.867\end{array}$ \\
\hline & $\begin{array}{l}\text { Outcome } \\
\text { evaluation }\end{array}$ & $\begin{array}{l}\text { The importance of health } \\
\text { The importance of distinctive flavor } \\
\text { The importance of good taste } \\
\text { The importance of nutritional } \\
\text { content }\end{array}$ & $\begin{array}{l}0.803 \\
0.890 \\
0.824 \\
0.868\end{array}$ \\
\hline \multirow{2}{*}{ Subjective Norms } & $\begin{array}{l}\text { Normative } \\
\text { Beliefs }\end{array}$ & $\begin{array}{l}\text { Family } \\
\text { Friends/relatives } \\
\text { Doctor/nutritionist } \\
\text { Goverment }\end{array}$ & $\begin{array}{l}0.845 \\
0.899 \\
0.901 \\
0.788\end{array}$ \\
\hline & $\begin{array}{l}\text { Motivation to } \\
\text { Comply }\end{array}$ & $\begin{array}{l}\text { Family } \\
\text { Friends/relatives } \\
\text { Doctor/nutritionist } \\
\text { Goverment }\end{array}$ & $\begin{array}{l}0.883 \\
0.927 \\
0.923 \\
0.798\end{array}$ \\
\hline \multirow{2}{*}{$\begin{array}{l}\text { Perceived } \\
\text { Behavioural } \\
\text { Control }\end{array}$} & Control Beliefs & $\begin{array}{l}\text { Financial issue } \\
\text { Availability of shrimp } \\
\text { Health (allergic, etc) }\end{array}$ & $\begin{array}{l}0.836 \\
0.898 \\
0.919 \\
\end{array}$ \\
\hline & $\begin{array}{l}\text { Power of } \\
\text { Control } \\
\text { Factors }\end{array}$ & $\begin{array}{l}\text { Sufficiency of money } \\
\text { Abundant availability } \\
\text { Health support }\end{array}$ & $\begin{array}{l}0.919 \\
0.919 \\
0.913\end{array}$ \\
\hline Intention & & $\begin{array}{l}\text { Intention to consume shrimp once a week } \\
\text { Intention to consume shrimp in restaurant }\end{array}$ & $\begin{array}{l}0.928 \\
0.908\end{array}$ \\
\hline
\end{tabular}

Based on the results of the analysis (Table 6), all indicators has loading factor's value more than 0.6. This indicates that all indicators can reflect latent variables and no need for dropping process.

\subsection{Average Variance Extraced (AVE) Composite Reliability, \& Discriminant Validity (Cross Loading)}

The next test for the convergent validity is by looking at the Average Variance Extracted (AVE) value on the reflective indicator model. The model requirement has good validity if each latent variable with reflective indicator has AVE value above 0.5 .

The results in Table 7 shows that the AVE value of each latent variable is $>$ 0.5, it means that the PLS model has a good convergent validity. The results in Table 7 also shows that all latent variable have good reliability, accurate and consistent. It because the model are eligible with composite reliability values that is > 0.7 and it means that the model has good reliability. 
INDEPENDENT JOURNAL OF MANAGEMENT \& PRODUCTION (IJM\&P)

http://www.ijmp.jor.br

v. 9, n. 3, July - September 2018

ISSN: 2236-269X

DOI: 10.14807/ijmp.v9i3.705

Table 7: Average Variance Extraxted (AVE)

\begin{tabular}{|l|l|c|}
\hline Variable & AVE & Composite Reliability \\
\hline Attitude Towards Behavior & 0,595 & 0.921 \\
\hline Perceived Behavioural Control & 0,766 & 0.951 \\
\hline Subjective Norms & 0,651 & 0.937 \\
\hline Behaviour beliefs & 0,640 & 0.876 \\
\hline Control beliefs & 0,784 & 0.915 \\
\hline Power of control & 0,841 & 0.941 \\
\hline Intention & 0,843 & 0.915 \\
\hline Motivation to Comply & 0,783 & 0.935 \\
\hline Normative beliefs & 0,739 & 0.918 \\
\hline Outcome evaluation & 0,725 & 0.913 \\
\hline
\end{tabular}

Discriminant validity testing is conducted on the principle that different construct manifest variables should not be highly correlated (Ghozali 2015). The evaluation performed for crossloading is that the indicator has a greater loading value of the original latent construct. Based on the research result, all cross loading value are already has a greater value in the original construct than the other constructs.

Based on the explanation of the measurement model, it is shows that the measurement model in this study has met all four criteria. This indicates that both models have good model validity and reliability.

\subsection{Evaluation of Structural Model (Inner Model)}

Evaluation of structural model can be seen from $R$ square value which is goodness-fit test model. Table 8 shows R-square value from this research.

Table 8: R-Square Value

\begin{tabular}{|l|l|}
\hline \multicolumn{1}{|c|}{ Variable } & \multicolumn{1}{c|}{ R-square } \\
\hline Behaviour beliefs & 0.854 \\
\hline Control beliefs & 0.937 \\
\hline Control factor & 0.946 \\
\hline Intention & 0.405 \\
\hline Motivation to comply & 0.867 \\
\hline Normative beliefs & 0.845 \\
\hline Outcome evaluation & 0.888 \\
\hline
\end{tabular}

Based on Table 8, the R-square value of $40.51 \%$ for intention means $40.51 \%$ of the variables in the model can explain the intention variables while the remaining $59.41 \%$ is explained by other factors not included in the model. The result of bootstrapping in Table 8 shows seven paths having significant influence (T-statistic> $\mathrm{T}$-table 1.96 at $5 \%$ real level). While the two paths are not significant ( $\mathrm{T}$-statistic $<\mathrm{T}$ table 1.96). The result can be seen on the following table. 
INDEPENDENT JOURNAL OF MANAGEMENT \& PRODUCTION (IJM\&P)

http://www.ijmp.jor.br

v. 9, n. 3, July - September 2018

ISSN: 2236-269X

DOI: 10.14807/ijmp.v9i3.705

Tabel 9: Inner Model Value

\begin{tabular}{|l|l|l|l|}
\hline Independent Variable & $\begin{array}{l}\text { Dependent } \\
\text { Variable }\end{array}$ & t-Statistics & $\begin{array}{l}\text { Significant/Not } \\
\text { significant }\end{array}$ \\
\hline Attitude Towards Behavior & Intention & 1.063 & Not significant \\
\hline Perceived Behavioural Control & Intention & 1.416 & Not significant \\
\hline Subjective Norms & Intention & 2.320 & Significant \\
\hline
\end{tabular}

As seen in table 9 also in Figure 3 below, subjective norms has a significant effect which directly affects the intention. In addition, it can be concluded that the acceptable hypothesis is $\mathrm{H} 2$ (subjective norms affect the intention to consume shrimp).

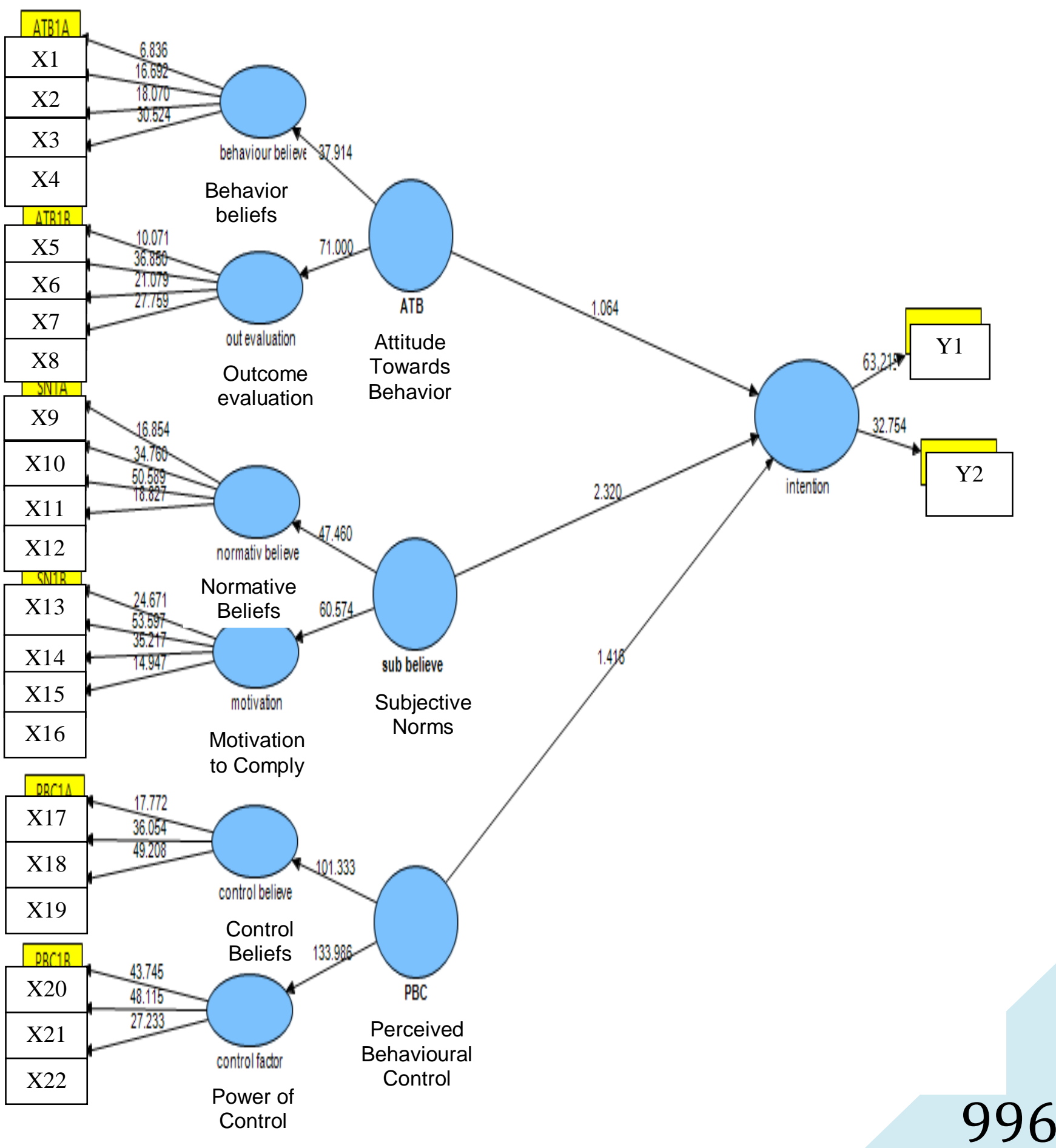


Figure 3: Inner Model of Theory of Planned Behavior

Based on the results of the analysis, the variables that significantly affects the intention of shrimp consumption is Subjective Norms. It means that the influence of social pressure perceived by consumers affect consumer's intention to consume shrimp. Social pressures are come from family, friends or relatives, doctors or nutritionists, and the most important role is the government.

\subsection{Managerial Implications}

By the results of this research, it shows that subjective norm is the variable that most influence the intention to consume shrimp. The influence of the environment are greatly affects consumers in taking decisions before making a purchase of shrimp products. The government in its program or policy has initiated an approach to the domestic consumers of seafood products in order to create high attention. According to Chiras and Reganold (2010), government regulations may affect consumer behavior in policies such as regulation, standardization, education and planning.

The government as the biggest shareholder in educating the public to consume fishery products, especially shrimp. Based on Gadda et al (2012), states that government regulations formally affect the pattern of seafood consumption in Japan. The Japanese government has gone through a long journey to create a culture of eating fish among Japanese society. Until now, although the pattern of seafood consumption in Japan exceeds capacity and threatens the world's fish stocks are getting smaller, the Japanese government continues to promote seafood as a healthy food.

The managerial implication that can be done by the government is to issue a mutually beneficial policy between government, business actors, consumers, and producers such as establishing National Eating Fish Day every year or month. The government should also require all stakeholders to participate. Product innovation can also be an income generating factor in the fishery industry as well as increasing public intention in consuming fishery products. 
INDEPENDENT JOURNAL OF MANAGEMENT \& PRODUCTION (IJM\&P)

http://www.ijmp.jor.br

v. 9, n. 3, July - September 2018

ISSN: 2236-269X

DOI: 10.14807/ijmp.v9i3.705

In addition, there should also be a mapping of marketing strategies for shrimp commodities. A good approach to mapping a marketing strategy is to consist of 7P, which is product, price, place, promotion, people, process, and physical evidence.

In terms of products, producers and distributors or young entrepreneurs should be able to change the paradigm on the market, where fish and shrimp are known as expensive products, have high cholesterol, have thorns, not practical, and various other negative views.

The results from this research showed that respondents prefer fresh shrimp products. Product intentions can be increased by innovating the products. For example, freshly spiced shrimp products, so consumers need only a short time to process the shrimp. Product quality also increases consumer confidence in fishery products.

High shrimp prices can be handled by minimizing the gramation of shrimp products. Innovation of processed products or giving a little added value makes the producers gain many benefits. In accordance with the results of the study, respondents used to buy shrimp in the amount of less than $1 \mathrm{kgs}$. Family packed size or individually packed size also can be a good innovation.

Beside social media, a good place for promotion for fishery products is in class A supermarkets where consumers are obviously had a goal of buying or consuming healthy products. Consumer in supermarkets class A generally have a good type of work with a high enough income. Their expenses have been confirmed in SES A and A + as the price of the goods in the supermarket is above the market price.

Good promotions also can be held by giving a free tester to people for trying shrimp. So that, consumers will pay attention in a good taste and good freshness shrimp. Manufacturers can also create a recipe book so that consumers can be creative with their products. Manufacturers can also provide promotional free trips to where the producer fish obtained, such as to Wakatobi or inland Indonesia which is still good. This is done as well as educate the consumers that the products they boght are come from good waters and in good production.

The government also has other programs such as the cheap fish market. If business people can capture these moments as well as build their social media so 
INDEPENDENT JOURNAL OF MANAGEMENT \& PRODUCTION (IJM\&P)

http://www.ijmp.jor.br

v. 9, n. 3, July - September 2018

ISSN: 2236-269X

DOI: 10.14807/ijmp.v9i3.705

that more and more people come to the fresh fish market. This will certainly increase the public's intention to buy shrimp and other fishery products either. The exhibition of various shrimp and fish preparations will make all visitors feel proud of the wealth of Indonesia and will be eager to consume them.

Products that have eco labels will be excellent for A-class market and millenials generation market. They want good food, in terms of quality and a good production process. Manufacturers can replace their raw materials with raw materials derived from unpolluted waters, well-educated fishermen make good and proper fishing. The cultivators also perform good cultivation activities and eco friendly. The attractive packaging for today's food consumers is that it has nutritional information.

Halal food is also becoming a warm conversation around the world. The country of Indonesia with its diversity but the majority of the religion of Islam will certainly be a potential market for fishery products. Production process in accordance with halal product provisions is the only way that must be done by the manufacturer. Education on halal products by displaying seafood products and their products will increase the intention of respondents to consume fishery products.

\section{CONCLUSION}

The result of model Theory of Planned Behavior toward shrimp consumer behavior shows that there is a significant affects directly to intention which is from Subjective Norm. This indicates that the acceptable hypothesis is $\mathrm{H} 2$ where subjective norms affect the intention to consume shrimp. Descriptively, the results of the distribution of questionnaires showed that majority of shrimp consumers were less than 30 years old, with private employment type and housewives.

\section{REFERENCES}

AJZEN, I. (1991). The theory of planned behaviour. Organizational Behaviour and Human Decission Processes, v. 50, p. 179-211

BADAN, P. S. (2011). Pengeluaran Untuk Konsumsi Penduduk Indonesia. Jakarta (ID): BPS

BADAN, P. S. (2014). Pengeluaran Untuk Konsumsi Penduduk Indonesia. Jakarta (ID): BPS

BARTON, C.; KOSLOW, L.; FROMM, J.; EGAN, C. (2012). Millenial Passion: Food, Fashion, and Friends. Bcg.perspective by The Boston Consulting Group. https://www.bcg.com/documents/file121010.pdf [16 Juli 2017] 
INDEPENDENT JOURNAL OF MANAGEMENT \& PRODUCTION (IJM\&P)

http://www.ijmp.jor.br

v. 9, n. 3, July - September 2018

ISSN: 2236-269X

DOI: 10.14807/ijmp.v9i3.705

BIRCH, D.; LAWLEY, M. (2010). A Conceptual Framework for Investigating Fish Consumption in Australia.

CHIN, W. (1998). The partial least squares approach to structural equation modelling. Modern Methods for Business Research. USA: Lawrence Erlbaum Associates.

CHIRAS, D. D.; REGANOLD, J. P. (2010). Natural Resource Conservation, Management for a Sustainable Future $\mathbf{1 0}^{\text {th }}$ Edition. Upper Saddle River (US): Pearson Prentice Hall

DALTOE, M. L. M.; CARRILLO, E.; QUEIROZ, M. I.; FISZMN, S.; VARELA, P. (2013). Structural equation modelling and word association as tools for a better understanding of low fish consumption. Food Research International, v. 52, p. 5663

FOTEA, L.; COSTACHESCU, E.; LEONTE, D.; NISTON, C. E. (2012). Research regarding consumer preferences in acquiring fish and fish products. Lucrări Ştiinţifice - Seria Zootehnie, v. 58, p. 112-115.

GADDA, T. M. C.; MARCOTULLIO, P. J. (2012). Changes in Marine Seafood Consumption in Tokyo, Japan. Desenvolvimento e Meio Ambiente, v. 26, p. 11-22.

GHOZALI, I. (2012). Aplikasi Analisis Multivariate dengan Program IBM SPSS 20. Semarang (ID): UNDIP.

GHOZALI, I.; HENGKY, L. (2015). Konsep, Teknik, Aplikasi Menggunakan SmartPLS 3.0 untuk Peneliti Empiris. Semarang (ID): BP Undip.

HONKANEN, P.; OLSEN, S. O.; VERPLANKEN, B. (2005). Intention to consume seafood-the importance of habit. Appetite, v. 45, p. 161-168

GHOZALI, I. (2012). Aplikasi Analisis Multivariate dengan Program IBM SPSS 20. Semarang (ID): UNDIP.

KEMENTRIAN, K. D. P. (2014). Kelautan dan Perikanan dalam Angka tahun 2014. Jakarta (ID): Pusat Data Statistik dan Informasi KKP.

LAUBER, T. B.; CONNELLY, N. A.; KNUTH, B. A.; NIEDERDEPPE, J. (2011). Factors influencing fish consumption in key audiences in the Great Lakes region. HDRU Publ. No. 11-8. Dept. of Nat. Resour., N.Y.S. Coll. Agric. and Life Sci., Cornell Univ., Ithaca, N.Y. 65 pp.

OLSEN, S. O. (2001). Consumer involvement in fish as family meals in Norway: An application of the expectance-value approach. Appetite, v. 36, p. 173-186.

SUMARWAN, U. (2011). Perilaku Konsumen: Teori dan Penerapannya dalam Pemasaran. Edisi Kedua. Bogor (ID): Ghalia Indonesia.

THOM, N. T. (2007). Attitude, motivation, and consumption of seafood in Bacninh province, Vietnam. [thesis]. Tromso (NO): University of Tromsø.

THONG, N. T., OLSEN, S. O. (2012). Attitude toward and Consumption of Fish in Vietnam. J. Food Products Marketing, v. 18, p. 79-95. 
TOMIĆ, M.; MATULIĆ, D.; JELIĆ, M. (2016). What determines fresh fish consumption in Croatia? Appetite, v. 106, p. 13-22

TUU, H. H.; OLSEN, S. O.; THAO, D. T.; ANH, N. T. K. (2008). The role of norms in explaining attitudes, intention and consumption of a common food (fish) in Vietnam. Appetite, v. 51, p. 546-551

TUU, H. H.; ANH, N. T. K.; OLSEN, S. O.; VASSDAL, T. (2010). Explaining repurchase intention towards in vietnam: the extension of the Theory of Planned Behaviour. IIFET 2010 Montpellier Proceedings.

VERBEKE, W.; VACKIER, I. (2005). Individual determinants of fish consumption: application of the theory of planned behaviour. Appetite, v. 44, p. 67-82 